\title{
Prince Edward Island
}

National Cancer Institute

\section{Source}

National Cancer Institute. Prince Edward Island. NCI Thesaurus. Code C89813.

A maritime province of eastern Canada consisting of the island of Prince Edward Island and other nearby islands. Its capital is Charlottetown. 